\title{
Water quality of rural ponds in the extensive agricultural landscape of the Cerrado (Brazil)
}

\author{
David Bichsel $^{2}$ Paulo De Marco Jr. ${ }^{1} \cdot$ Arthur Ângelo Bispo $^{1} \cdot$ Christiane Ilg $^{2}$ • \\ Karina Dias-Silva $^{1}$. Thiago Bernardi Vieira ${ }^{1}$ Caroline Costa Correa ${ }^{1} \cdot$ \\ Beat Oertli ${ }^{2}$
}

Received: 14 January 2015/ Accepted: 26 January 2016/Published online: 13 February 2016

(C) The Japanese Society of Limnology 2016

\begin{abstract}
The Brazilian Cerrado, one of the world's 34 biodiversity hotspots, is today under increasing pressure from the intensification of agriculture, with the replacement of traditional extensive pastures by arable crops. Manmade ponds are currently widespread in rural areas of the Cerrado and provide many ecosystem services such as cattle watering, fish production, irrigation and erosion protection. As in other parts of the world, ponds are also likely to play a critical role in the conservation of freshwater biodiversity, although in the Cerrado there is still very little known about their biota. Good water quality, in particular the level of eutrophication, is a key factor in maintaining aquatic biodiversity at the regional scale. Therefore, we aimed here to assess the water quality of ponds in the Cerrado. We also assessed whether the main types of socioeconomic pond uses have an impact on their water quality. We focused on measures of primary production and conducted socioeconomic inquiries for 56 waterbodies in the Goiânia Cerrado region (GO, Brazil) at the beginning of the 2012 dry season. Overall, differences in water quality appeared to be linked to the type of pond use. The trophic level, as indicated by the chlorophyll
\end{abstract}

Handling Editor: Junjiro N. Negishi.

Electronic supplementary material The online version of this article (doi:10.1007/s10201-016-0478-7) contains supplementary material, which is available to authorized users.

Beat Oertli

beat.oertli@hesge.ch

1 Laboratório de Ecologia Teórica e Síntese, ICB, Universidade Federal de Goiás, Goiânia, GO, Brazil

2 University of Applied Sciences and Arts Western Switzerland, Hepia Lullier, 1254 Jussy/Geneva, Switzerland concentration and conductivity, was greater in fish ponds and seemed to be related to management practices such as fish feeding and the type of water supply, in particular relatively low inflow volume. This contrasted with ponds used for cattle watering in extensive agricultural landscapes characterized by a low trophic level potentially beneficial for regional biodiversity. Good water quality in pasture ponds may be maintained by spring water inflow or heavy precipitation. Overall, the water quality of the Cerrado ponds was good compared with the same type of waterbodies in other regions of the world. These results highlight the high potential of the Cerrado ponds in extensive agricultural landscapes to provide an important habitat for aquatic biodiversity. Biodiversity inventories and assessments are now needed to increase our knowledge of these waterbodies and inform management activities at the local and regional scale.

Keywords Savannah - Small waterbodies - Reservoirs . Socioeconomic uses · Water quality $\cdot$ Chlorophyll

\section{Introduction}

Freshwater biodiversity is particularly threatened today (e.g., Dudgeon et al. 2006). Small waterbodies such as ponds play an important role in strategies aimed at conserving freshwater biodiversity (Oertli et al. 2010). Indeed, it has now been clearly recognized that they can support great species richness and many endangered species (Williams et al. 2003). Small standing waterbodies are extremely numerous in both natural and anthropogenic landscapes (Downing et al. 2006) and are very diverse in size, origin and uses. A pond is defined as a body of fresh water (occasionally brackish) that can vary in size from $1 \mathrm{~m}^{2}$ to 2 hectares and 
that holds water for 4 months of the year or more (Oertli et al. 2005) (see http://www.europeanponds.org). Small reservoirs that have been dug directly on streams are often also considered ponds as the water is generally lentic with a biocoenose typical of stagnant waterbodies. Human activities are often closely linked to pond origins and to their maintenance in the landscape. Artificial waterbodies can contribute significantly to regional freshwater biodiversity, as demonstrated for a wide variety of pond types, such as storm water ponds (Le Viol et al. 2009; Moore and Hunt 2012; Scher and Thiery 2005), reservoirs (Clements et al. 2006), irrigation pools (Abellan et al. 2006), farm ponds (Casas et al. 2012), traditional troughs (Garcia-Gonzalez and Garcia-Vazquez 2011), water treatment ponds (Becerra-Jurado et al. 2012), garden ponds (Davies et al. 2009) and fish ponds (Rosset et al. 2014; Wezel et al. 2014).

The Cerrado, one of the world's 34 biodiversity hotspots (Mittermeier et al. 2005), has been largely shaped by human activity. The present landscape mostly comprises extensive pastures, although since the 1970s these have been increasingly replaced by more intensive arable land (Klink and Machado 2005; Klink and Moreira 2002; Müller 2003; Schiesari and Grillitsch 2011). The extensive agricultural landscape of the Cerrado is characterized by the presence of an aquatic network of more or less connected streams and small manmade waterbodies (ponds and reservoirs). Many very small reservoirs were built along streams to sustain rural activities. The services provided by these small waterbodies include water supplies for cattle, domestic production of vegetables and fruits, domestic activities such as housecleaning, leisure activities (e.g., fishing), fish farming and erosion control. Furthermore, they may also act as nutrient traps and carbon sinks (Downing et al. 2006; EPCN European Pond Conservation Network 2008; Hansson et al. 2005). As in other parts of the world, ponds are also likely to play a key role in sustaining freshwater biodiversity by providing a habitat for a wide range of wildlife, including many endangered species. However, in the Cerrado, the potentially exceptional pond resource has not been investigated until now. The future evolution of the Cerrado, in particular the intensification of agriculture (Klink and Moreira 2002), will probably lead to a decrease in the number of these aquatic networks and is also likely to impact the water quality, as has already happened in industrialized countries (e.g., Brönmark and Hansson 2002). Nutrient enrichment leading to eutrophication will without doubt constitute one of the major factors impairing the pond networks in the Cerrado in the future, and this is likely to lead to a more homogenized network dominated by eutrophic to hypertrophic ponds and a likely decrease in regional biodiversity ( $\gamma$ biodiversity) (Rosset et al. 2014).

To understand the potential of the aquatic networks of ponds and small reservoirs to support the aquatic biodiversity of the Cerrado, one of the first steps is to assess the water quality and how it relates to waterbody types and uses. Therefore, the present investigation aims to: (1) describe the types of waterbodies present (e.g., sizes, origins and uses), (2) assess their quality (e.g., water quality) and (3) relate their use (ecosystem services) to their potential to support biodiversity. To achieve these objectives, we studied 56 ponds from several networks of waterbodies in a test area $\left(700 \mathrm{~km}^{2}\right)$ characteristic of the present Cerrado landscape, situated near the city of Goiania (GO, Brazil).

\section{Study site}

The Cerrado is a savannah ecosystem situated entirely in Brazil. It covers 2 million $\mathrm{km}^{2}$, which represents $22 \%$ of the country surface area (Oliveira Filho and Ratter 2002). It is the second largest South American biome and the most threatened because of land conversion from native vegetation to pasture and cropland (Balbino et al. 2002; Marris 2005). It belongs to one of the earth's richest biological and most endangered terrestrial eco-regions, also called biodiversity hotspots (Myers et al. 2000).

The Cerrado has a typical savannah climate, characterized by two distinct seasons: a warm and rainy summer (October-March) and a mild and dry winter (AprilSeptember). The annual rainfall is between 800 and $1600 \mathrm{~mm}$ (National Meteorology Institute, http://www. inmet.gov.br). Half of the Cerrado's soils, including those of the entire study area, are characterized as ferralsols (Motta et al. 2002; The Brazilian Institute of Geography and Statistics-IBGE, http://www.ibge.gov.br). These soils are usually well drained with low natural fertility and a relatively stable physical structure. Soil $\mathrm{pH}$ is between 4 and 6.1 (Motta et al. 2002).

Cerrado's biodiversity (flora, fauna and fungi) is estimated at 160,000 species. The number of endemic vascular plants has been recently estimated at 4400 species, which represents $1.5 \%$ of the worldwide vascular plant species. Endemism for vertebrate animals ranges from $3 \%$ for birds to $15 \%$ for amphibians (Oliveira and Marquis 2002).

There are several different types of landscape in the Cerrado. Today, more than half of the Cerrado's landscape has been modified by human activity. The annual deforestation has been higher in the Cerrado than in the Amazonian forest since the 1970s (Klink and Moreira 2002). According to these authors, the landscape distribution in 2005 was made up of $44.5 \%$ natural landscape, $41.6 \%$ planted grass landscape (cattle pasture), $11.4 \%$ agricultural crops (including planted forests) and $1.9 \%$ urban areas. The most common anthropic landscape in the Cerrado is extensive pasture (Sano et al. 1999) although arable 
fields, particularly soybean, are increasingly common in the landscape (Klink and Moreira 2002; Müller 2003).

The study area is located $25 \mathrm{~km}$ southeast of the city of Goiânia (GO, Brazil) and covers 70,000 hectares $(20 \times 35 \mathrm{~km})$ (Fig. 1). It has been chosen for its representativeness of the Cerrado's pasture landscape as it is characterized by open pastures separated by a few strips of natural savannah.

All waterbodies were identified by visual interpretation of satellite images in Google Earth. A total of 2787 ponds were found in the study area (about $4.5 / \mathrm{km}^{2}$ ), reflecting a pond network much denser than in most parts of the world (e.g., densities presented in Downing et al. 2006). A total of 56 ponds were selected using a stratified random design according to size and isolation (Table 1). The surface area of the selected ponds varied from 50 to $9000 \mathrm{~m}^{2}$, whereas the distance to the nearest pond varied from 107 to $1207 \mathrm{~m}$.

\section{Materials and methods}

The 56 ponds were surveyed at the beginning of the dry season (5 June-6 July 2012). During that time, data on the socioeconomy, waterbody morphometry and water physicochemistry were collected.

Standardized information including pond age, pond uses, management (e.g., fish feeding) and water supply was collected from enquiries to landowners. Four types of water supply were distinguished: direct stream water (the inlet is the stream itself), stream water from a stream derivation
Table 1 Distribution of the sampled ponds in relation to pond size and isolation in the study area

\begin{tabular}{llllll}
\hline Surface area $\left(\mathrm{m}^{2}\right)$ & \multicolumn{5}{l}{ Isolation $(\mathrm{m})$} \\
\cline { 2 - 6 } & 300 & 500 & 700 & 900 & $>900$ \\
\hline 190 & 2 & 2 & 1 & - & 1 \\
600 & 3 & 1 & 2 & - & 4 \\
1900 & 5 & 2 & 2 & 4 & 4 \\
6000 & 3 & 3 & 2 & 1 & 1 \\
10000 & 3 & 2 & 2 & 3 & 3 \\
\hline
\end{tabular}

Pond isolation was measured as the linear distance to the nearest neighbor pond

(ditch), stream water from a small stream derivation (pipe) and no stream water inflow (i.e., rain water and surface runoff were the only water sources). The volume of the inflow varied according to the type of water supply: from very high for direct stream inflow, medium for ditch inflow, low for pipe inflow and null for rainwater-fed ponds.

All physical and chemical data were measured in situ. As heavy rain can dilute the concentration of solutes in ponds, water chemistry measurements were undertaken only if no rain had been recorded during the preceding 3 days. Water transparency was measured using a modified Snellen method: a piece of plastic marked with alphabetical characters from $\mathrm{A}$ to $\mathrm{N}$ was connected to a ruler. It was dipped into the pond water, and when the letters started to become unreadable, the depth was recorded in centimeters.

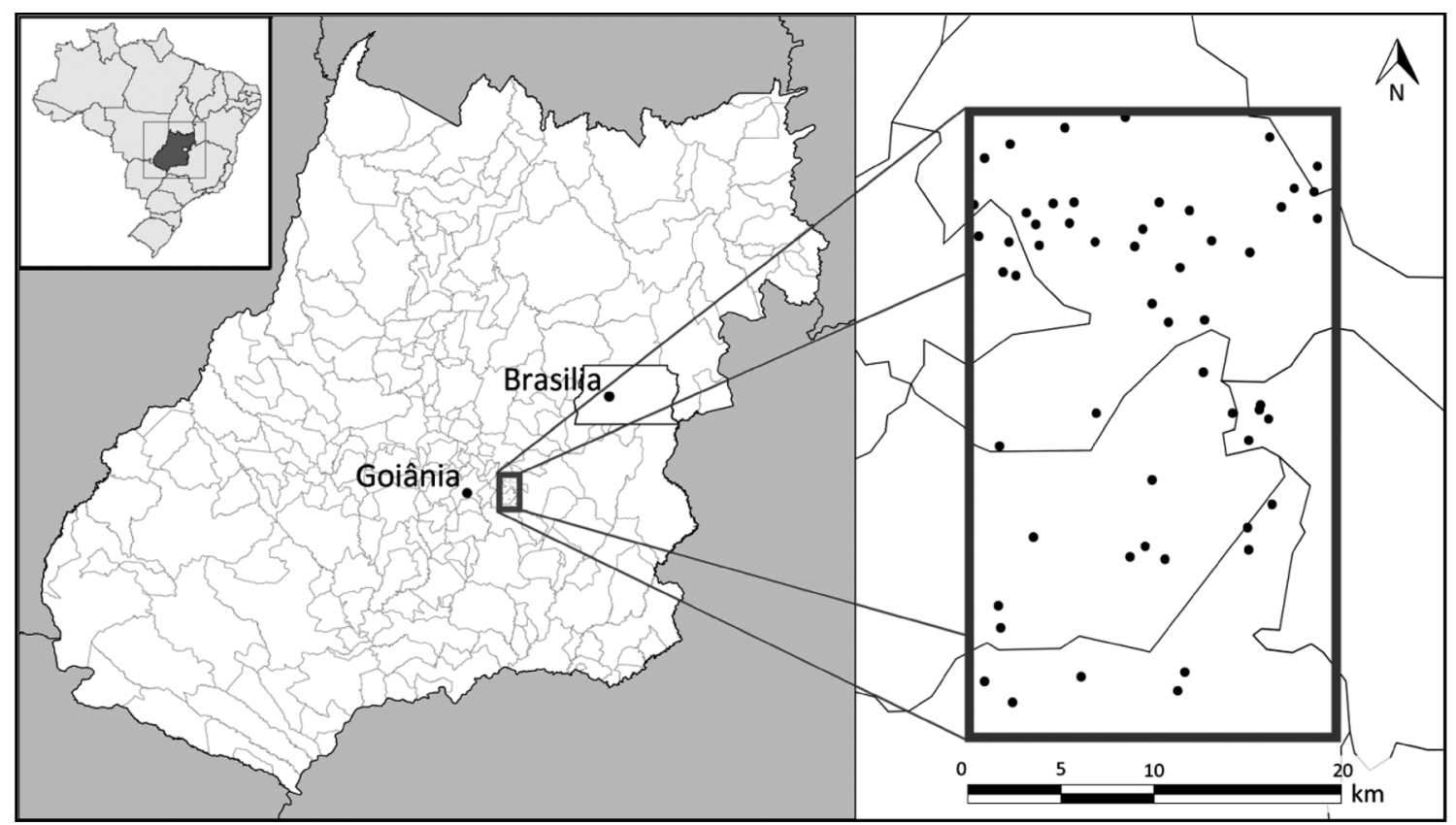

Fig. 1 Location of the study area $(20 \times 35 \mathrm{~km})$ and the waterbodies surveyed, close to the city of Goiania, state of Goiás, Brazil 
The values obtained using this method are clearly correlated to those obtained by the Snellen method (Oertli, unpublished data).

Total chlorophyll, pH, dissolved oxygen (DO), conductivity and temperature were measured using a YSI 6820 v2 multiparameter water quality probe with the $\mathrm{pH}$ sensor YSI 6565, chlorophyll sensor YSI 6025 and oxygen sensor YSI 6150. A water sample was taken from the middle of the pond at $30 \mathrm{~cm}$ depth with a bucket. All variables were measured once during the study period. However, for quality control purposes, selected ponds were sampled at higher frequency. Sixteen ponds were sampled twice in order to test the impact of heavy rain on the physicochemical variables collected. In addition to the 56 ponds surveyed, a quality control for $\mathrm{pH}$ and oxygen values was undertaken using continuous monitoring in order to assess the magnitude of temporal variability (day-night; season) on two additional ponds. The loggers were positioned at $3 \mathrm{~m}$ from the shore in a place characterized by a depth of $60 \mathrm{~cm}$ (water level typical of the rainy season). They were situated at mid-depth of the water column, i.e., $30 \mathrm{~cm}$ from the substrate (and $30 \mathrm{~cm}$ from the water surface). Measures were recorded continuously (every $30 \mathrm{~min}$ ) in one fish pond during a 10-day period (end of the rainy season; February 2013) using the HOBO U26 dissolved oxygen data logger and WTW WQL-pH pH data logger (Online Supplementary: Appendix 1). Similarly, temperature and conductivity measurements were collected between the 15 February and 7 September 2013 (covering the dry and rainy season) in both a fish and cattle watering pond (Online Supplementary: Appendix 2). The results of these continuous monitoring programs evidenced high nycthemeral variability of oxygen, $\mathrm{pH}$ and temperature values; for this reason, these three parameters were not used in the statistical analyses (as the 56 ponds were measured only once). The data are nevertheless presented here as they collectively present an overview of the range of values that can be measured in the ponds studied.

Relations between total chlorophyll concentrations and potential predictor variables (surface area, pond age, pond use and type of water supply) were assessed by mean of generalized linear models (GLMs) with a Gaussian distribution. An iterative stepwise backward selection was used to select the most predictive variables to be kept in the model. First, a full model including all four predictor variables was built. A model simplification procedure based on Akaike's information criterion (AIC) was then used to remove the less informative parameters included in the start model, with the model having the lowest AIC value being selected as the best approximating model (Symonds and Moussalli 2011). Prior to analyses, the pond surface, pond age and total chlorophyll concentration were $\log$ transformed. Pond use was integrated in the models as a factor with three levels (fish pond, cattle watering pond and other usages) and water supply as a factor with two levels (stream fed, not stream fed).

Testing for spatial autocorrelations was carried out by means of Mantel tests using Euclidian distance matrices for continuous variables and Gower distance matrices for categorical variables. Among the tested variables, only age showed a weak spatial dependence (Mantel test statistic $r$ : 0.1606, significance: 0.046). Therefore, the effects of spatial autocorrelations were not taken into account in the analyses.

\section{Results}

\section{Socioeconomic characteristics of ponds}

Most of the 56 studied ponds were relatively young: all except one were created less than 50 years ago. Five types of main uses characterize them (Fig. 2 and Online
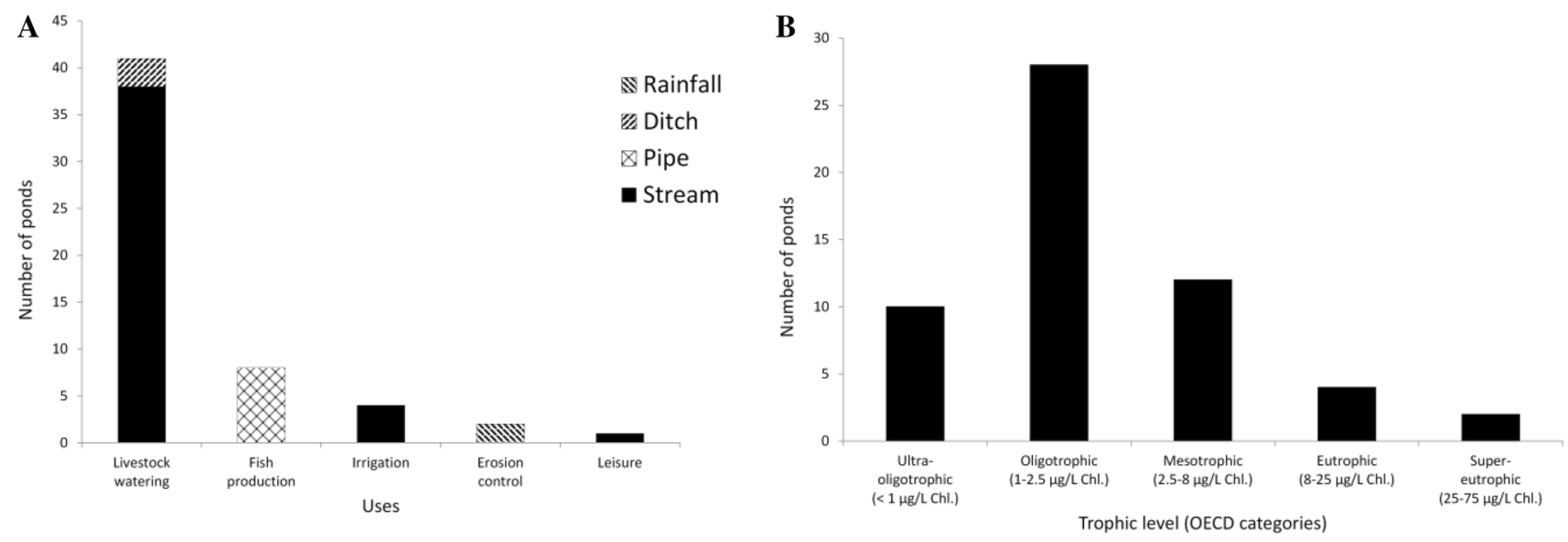

Fig. 2 Prevailing uses of the 56 studied ponds and types of water supply (a) and pond trophic levels (b) 
Supplementary: Appendix 3). As the investigated area is dominated by pastures, most of the ponds (41) were used for cattle watering. Eight were used for local fish production and the remaining seven for other various uses (e.g., irrigation, erosion control, leisure). Direct anthropic inputs of nutrients took place only in the fish ponds through fish feeding by landowners.

Fish ponds were often located just beside the owner's houses while those used for cattle watering were mostly located in pastures. Fish production was rarely commercialized and was mostly consumed by the owners and their relatives.

The type of water supply, and so the quantity of the water supply (and the rate of water renewal), was the other main variable linked to anthropic interventions characterizing the ponds: most (43) of the 56 investigated ponds were stream impoundments (small dams) and therefore were fed by a large volume of water from small streams. Of these 43 "stream-fed ponds," 29 were located less than $500 \mathrm{~m}$ from the springs. The springs were located further away for the other 14 ponds. Three other ponds were fed by a diversion ditch from the stream ("ditch-fed ponds"). For eight ponds, all fish ponds, the inflow was a pipe linked to the stream ("pipe-fed ponds"), which supplied a smaller volume of water than via the diversion ditch and prevented fish from escaping from the pond. Two other ponds had no inflow and were fed by rain and surface water runoff. Ponds used for cattle watering were almost all stream-fed.

\section{Water quality}

Total chlorophyll (Fig. 2) ranged from 0.2 to $33.5 \mu \mathrm{g} / \mathrm{l}$, with a mean of $4.2 \mu \mathrm{g} / \mathrm{l}$ (standard deviation 6.7), which corresponds to the mesotrophic category of the OECD classification (OCDE 1982). According to this classification, $18 \%$ of the ponds are characterized as ultra-oligotrophic $(<1 \mu \mathrm{g} / \mathrm{l}), 50 \%$ as oligotrophic $(1-2.5 \mu \mathrm{g} / \mathrm{l})$, $21 \%$ as mesotrophic $(2.5-8 \mu \mathrm{g} / \mathrm{l}), 7 \%$ as eutrophic $(8-25 \mu \mathrm{g} / \mathrm{l})$ and $4 \%$ as hypertrophic $(25-75 \mu \mathrm{g} / \mathrm{l})$. Transparency values ranged from 10 to $80 \mathrm{~cm}$, with a mean of $29 \mathrm{~cm}$ (SD 13). Pond $\mathrm{pH}$ values ranged from slightly acid (6.4) to basic (8.5), with a mean of 7.1 (SD 0.4). Conductivity was often low and ranged from 11 to $227 \mu \mathrm{S} / \mathrm{cm}$, with a mean value of $78 \mu \mathrm{S} / \mathrm{cm}$ (SD 58).

The detailed measurements of all water parameters are presented in Online Supplementary: Appendix 3.

\section{Relationships among the water quality, environmental variables and pond use}

The relationships among the four main local variables (total chlorophyll, water transparency, conductivity, pond surface area) were explored through a Spearman correlation test. The
Table 2 Final generalized linear model results for the total chlorophyll concentration in the water of the Cerrado ponds, including the parameter estimates, standard errors (SE) and significance levels

\begin{tabular}{llll}
\hline Explanatory variable & Estimate & SE & $p$ \\
\hline Pond use (cattle watering) & -0.6509 & 0.152 & $9.88 \mathrm{E}-05$ \\
Pond use (other usages) & -0.6394 & 0.2205 & 0.00581 \\
\hline
\end{tabular}

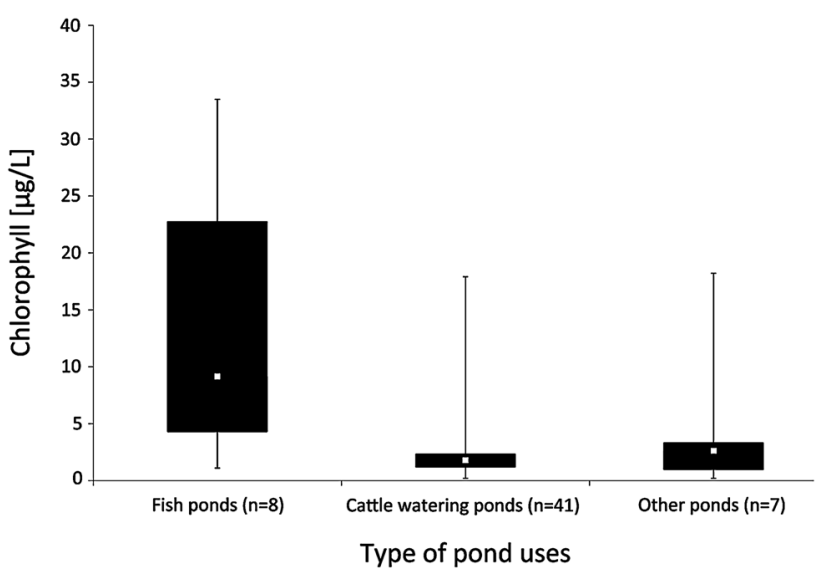

Fig. 3 Total chlorophyll concentration in ponds with the three types of uses: fish production, cattle watering and other uses

concentration in total chlorophyll (as a surrogate for productivity or for nutrient concentrations, i.e., water quality) was negatively correlated with water transparency $(r=-0.264, p=0.049)$. Indeed, ponds identified as eutrophic or hypertrophic tended also to have low water transparency. Water transparency was also negatively correlated with conductivity $(r=-0.502, p=0.0001)$.

Among the four predictor variables selected in the GLM models (surface area, pond age, pond use and type of water supply), only pond use was kept in the final GLM model, which evidenced the strong effect of this variable on total chlorophyll concentrations (Table 2). Overall, the model explained about $30 \%$ of the deviance. The detailed steps of the model selection are shown in Online Supplementary: Appendix 4.

Total chlorophyll concentration was significantly higher in fish ponds than in the cattle watering ponds and in the other pond types (Fig. 3). Most of fish ponds were classified as mesotrophic or eutrophic, but most of the cattle watering ponds and other ponds were oligotrophic.

\section{Discussion}

According to the latest classification of biodiversity hotspots, the Cerrado is the sixth most important biogeographic area in the world, with its high biological richness especially threatened by human activities (Myers et al. 
2000). This is a result of massive clearing of native vegetation to replace it by arable land or pasture. In our studied area, cleared land was mainly transformed into pasture, but the cropland area is expected to expand in the future. The present trend is toward agricultural intensification and a landscape dominated by irrigated crops (Carvalho et al. 2009). In this context of a changing landscape, the aquatic networks existing today will most likely suffer important physical (e.g., damming, draining) and chemical (water pollution) impairments, including increased nutrient inputs leading to eutrophication (Firbank et al. 2008; Matson et al. 1997). It is therefore crucial to assess the water quality of the existing networks and its contribution to the Cerrado's biodiversity.

The prevailing pond use in the investigated area was cattle watering, which is consistent with what is observed in many Cerrado areas characterized by cattle-raising activities. Fish ponds are also common, as they represent an additional economic gain or leisure activity. Irrigation ponds were less common as irrigation is usually associated with more intensive land uses. Our study showed that most of the ponds studied had low levels of total chlorophyll at the beginning of the dry season, with most values being typical of oligotrophic conditions. This is markedly below the trophic level measured in ponds from other regions of the world where mostly eutrophic or hypertrophic conditions are prevalent (e.g., Barbe et al. 2000; Declerck et al. 2006; Hiramatsu et al. 2005; Kadoya et al. 2011; Kuczynska-Kippen and Joniak 2009; Oertli et al. 2000; Robin et al. 2014; Rosset et al. 2014). Comparisons have to be made with caution as these studies were realized in temperate climates. However, the chlorophyll concentrations found in this study were also lower in the Cerrado ponds than those reported for other types of tropical waterbodies from Brazil, such as dam reservoirs, for example (Tundisi et al. 1993; Rodgher et al. 2005). Similarly, conductivity values (mean: $78 \mu \mathrm{S} / \mathrm{cm}$ ), another potential indicator of impairment, were also clearly low.

Nutrient enrichment (and the consequent increase in primary production) is a major impairment of aquatic systems and has a direct impact on local and regional biodiversity. It is well known that in general ecosystem biodiversity (local biodiversity) decreases in ecosystems suffering nutrient enrichment (Carson and Barett 1988; Odum and Barret 2005).

The relationship between the eutrophication of freshwater systems and biodiversity (species richness and threatened species) tends to follow a hump-shaped pattern, with the highest richness in mesotrophic conditions (Mittelbach et al. 2001; Waide et al. 1999). A negative relationship between high nutrient load and local biodiversity is particularly clear when looking at macrophyte species richness (Rosset et al. 2014; Wezel et al. 2014). The humpshaped curve nevertheless characterizes the local species richness (pond scale). At the regional scale, the speciespoor oligotrophic systems are expected to make a unique contribution (e.g., with specialized species) to the regional richness (e.g., Rosset et al. 2014), therefore enriching it.

The mainly low to medium chlorophyll concentration values obtained in the 56 Cerrado ponds are therefore indicators that these waterbodies have good potential for supporting a biodiversity with a high conservation value (e.g., specialized species, often rare and endangered). A study focusing on pond biodiversity, carried out in the same set of freshwater bodies, confirmed that these ponds are colonized by diverse bird, amphibian, fish and macroinvertebrate communities as well a large number of algae species and macrophytes (De Marco et al. 2014). Amphibians and beetles were likely to be sensitive to eutrophication. This study nevertheless has to be supplemented by additional investigations to better assess the conservation statutes of the different groups and the driving variables at the regional scale.

The low chlorophyll concentration values found in most of the studied ponds are probably linked to: (1) the extensive nature of the dominant agricultural land use in the studied area (cattle pasture), with low or no use of fertilizers in the catchment, (2) good stream water quality (ponds are mostly situated near springs toward the top of catchments) and (3) pond water dilution due to large amounts of rainwater. Indeed, of the 56 studied ponds, 35 were fed by springs located nearby. Groundwater in areas with low intensity land use (e.g., where there are no or a low input of fertilizers) has reduced nutrient loads compared to streams, and concentrations of other dissolved elements are also lower as the soil acts as a filter. Furthermore, an unexpected rain occurred at the beginning of the data collection campaign, contributing to water dilution.

Our results show that the two dominant types of socioeconomic pond use in the study area, cattle watering and fish production, had different impacts on water quality. Ponds in cattle pastures had low chlorophyll concentrations and oligotrophic conditions. In contrast, fish ponds had higher chlorophyll concentrations, typical of mesotrophic to eutrophic conditions, and were therefore still suitable for supporting diversified communities. High productivity in fish ponds is linked to management practices: in all cases, fish feeding took place almost daily. Food that is not directly consumed by fish tends to settle on the sediment where microbial decomposition takes place and oxygen is consumed. Once mineralized, the elements are available for uptake by phytoplankton and promote their development. According to Verdegem (2007), only $20 \%$ of the nitrogen and phosphorus entering as food is eaten by fish; the rest $(80 \%)$ ends up in the sediment. Fish feeding certainly has a much greater impact on water quality during the dry season when it can potentially lead to major anoxia 
and even fish mortality, an event reported by farmers during socioeconomic enquiries. In the future, it will therefore also be important to monitor water quality during the dry season, especially in fish ponds. Another management practice likely to reduce water quality in fish ponds is the inflow water volume. This tended to be small in fish ponds and was managed by pond owners through small pipes. In contrast, pasture ponds were generally fed by small stream/ditch inflows ensuring a greater volume of clean water entering the pond and helping to maintain good water quality.

In conclusion, our study shows that ponds in the extensive agricultural landscape from the Cerrado have good water quality at the beginning of the dry season and are likely to be important as a habitat for aquatic fauna and flora, contributing therefore to the regional biodiversity. Ponds used for cattle watering, which represent the majority of waterbodies, show little impairment, suggesting that extensive use as grazing land maintains good water quality in ponds. However, the ponds used for fish production, which are less frequent in the landscape, tend to have lower water quality, and this is clearly linked to management practices.

The next steps are now (1) to monitor pond quality in the long term (one to several years), (2) to inventory the biodiversity of ponds and (3) to assess the contribution of ponds to the conservation of the Cerrado's freshwater biodiversity on a regional scale. These two last steps have recently been initiated: biological surveys are in progress (de Marco et al. 2014) in both the study area and other parts of the Cerrado. The results of these physicochemical and biological studies will inform management recommendations to maintain the biodiversity value of the pond resource. This information will be disseminated to land managers and the political authorities to help influence policies linked to the conservation of freshwater in the Cerrado.

The Cerrado is changing very quickly because of the intensification of agriculture, and its land use is switching from grassland to cropland, increasingly causing degradation of surface water ecosystems. Nutrient enrichment and pesticide residues will undoubtedly increase in the short term (Dudgeon et al. 2006; Schiesari and Grillitsch 2011) and so will the threat to the Cerrado's unique biodiversity. It is therefore crucial to intensify research that will directly inform freshwater biodiversity conservation and management in this part of the world.

Acknowledgments This work has been realized in the larger framework of the applied research program "Promotion of small waterbodies networks in the biodiversity hotspot "Cerrado" (Brazil), for their dual services to rural activities and to biodiversity," a project founded by the KFH Development and Coordination office, http:// www.kfh.ch/dc. David Bichsel benefited from grants offered by SGHL (Swiss Society of Hydrology and Limnology) and inTNE (Land Nature and Environment Institute, hepia) and the international relationship with HESSO (University of Applied Sciences and Arts of Western Switzerland). Paulo De Marco is supported by continuous $\mathrm{CNPq}$ productivity grants. Technical support for the use of loggers was provided by Eliane Demierre (hepia). We are very grateful to all landowners and farmers for their hospitality and warm welcome. Thanks to Pascale Nicolet for her language review and for the other suggestions that greatly improved the quality of this manuscript. The manuscript also benefited greatly from insightful comments made by external referees.

\section{Compliance with ethical standards}

Ethical standards The experiments conducted comply with the current laws of Brazil.

Conflict of interest The authors have no financial relationship with the organizations that sponsored the research. The authors have full control of all primary data and agree to allow the journal to review the data if requested.

\section{References}

Abellan P, Sanchez-Fernandez D, Millan A, Botella F, SanchezZapata JA, Gimenez A (2006) Irrigation pools as macroinvertebrate habitat in a semi-arid agricultural landscape (SE Spain). J Arid Environ 67:255-269

Balbino LC, Brossard M, Leprun JC, Bruand A (2002) Development of agriculture on ferralsols in the Cerrado region (Brazil) and change of their physical properties (in French). Étude et Gestion des Sols 9:83-104

Barbe J, Schlumberger O, Bouertz N (2000) Evaluation of the ponds potential fish production (in French). Ingénieries EAT 22:49-62

Becerra-Jurado G, Harrington R, Kelly-Quinn M (2012) A review of the potential of surface flow constructed wetlands to enhance macroinvertebrate diversity in agricultural landscapes with particular reference to integrated constructed wetlands (ICWs). Hydrobiologia 692:121-130

Brönmark C, Hansson LA (2002) Environmental issues in lakes and ponds: current state and perspectives. Environ Conserv 29:290-307

Carson WP, Barett GW (1988) Succession in old-field communities: effects of contrasting types of nutrient enrichment. Ecology 69:984-994

Carvalho FMN, De Marco P, Ferreira LG (2009) The Cerrado intopieces: habitat fragmentation as a function of landscape use in the savannas of central Brazil. Biol Conserv 142:1392-1403

Casas JJ, Toja J, Penalver P, Juan M, Leon D, Fuentes-Rodriguez F, Gallego I, Fenoy E, Perez-Martinez C, Sanchez P, Bonachela S, Elorrieta AM (2012) Farm ponds as potential complementary habitats to natural wetlands in a Mediterranean region. Wetlands 32:161-174

Clements R, Koh LP, Lee TM, Meier R, Li DQ (2006) Importance of reservoirs for the conservation of freshwater molluscs in a tropical urban landscape. Biol Conserv 128:136-146

Davies ZG, Fuller RA, Loram A, Irvine KN, Sims V, Gaston KJ (2009) A national scale inventory of resource provision for biodiversity within domestic gardens. Biol Conserv 142:761-771

De Marco P Jr, Nogueira DS, Correa CC, Vieira TB, Silva KD, Pinto NS, Bichsel D, Hirota ASV, Vieira RRS, Carneiro FM, de Oliveira AAB, Carvalho P, Bastos RP, Ilg C, Oertli B (2014) Patterns in the organization of Cerrado pond biodiversity in Brazilian pasture landscapes. Hydrobiologia 723:87-101 
Declerck S, De Bie T, Ercken D, Hampel H, Schrijvers S, Van Wichelen J, Gillard V, Mandiki R, Losson B, Bauwens D, Keijers S, Vyverman W, Goddeeris B, De Meester L, Brendonck L, Martens K (2006) Ecological characteristics of small farmland ponds: associations with land use practices at multiple spatial scales. Biol Conserv 131(4):523-532

Downing JA, Prairie YT, Cole JJ, Duarte CM, Tranvik LJ, Striegl RG, McDowell WH, Kortelainen P, Caraco NF, Melack JM, Middelburg JJ (2006) The global abundance and size distribution of lakes, ponds, and impoundments. Limnol Oceanogr 51:2388-2397

Dudgeon D, Arthington AH, Gessner MO, Kawabata ZI, Knowler DJ, Leveque C, Naiman RJ, Prieur-Richard AH, Soto D, Stiassny MLJ, Sullivan CA (2006) Freshwater biodiversity: importance, threats, status and conservation challenges. Biol Rev 81:163-182

EPCN European Pond Conservation Network (2008) The pond manifesto. EPCN, Oxford

Firbank LG, Petit S, Smart S, Blain A, Fuller RJ (2008) Assessing the impacts of agricultural intensification on biodiversity: a British perspective. Philoso Trans Royal Soc B 363:777-787

Garcia-Gonzalez C, Garcia-Vazquez E (2011) The value of traditional troughs as freshwater shelters for amphibian diversity. Aquat Conserv Marine Freshw Ecosys 21:74-81

Hansson LA, Brönmark C, Nilsson PA, Abjornsson K (2005) Conflicting demands on wetland ecosystem services: nutrient retention, biodiversity or both? Freshw Biol 50:705-714

Hiramatsu K, Yanagihara C, Ichion E (2005) Socio-physical environments and algae/water quality properties of irrigation ponds: case study in Minakuchi and Otsu, Japan. Off $\mathbf{J}$ Int Assoc Lowl Technol 7(2):1-7

Kadoya T, Akasaka M, Aoki T, Takamura N (2011) A proposal of framework to obtain an integrated biodiversity indicator for agricultural ponds incorporating the simultaneous effects of multiple pressures. Ecol Ind 11(5):1396-1402

Klink CA, Machado RB (2005) The conservation of the Brazilian Cerrado. Conserv Biol 19:707-713

Klink CA, Moreira AG (2002) Past and current human occupation, and land use. In: Oliveira PS, Marquis RJ (eds) The Cerrados of Brazil. Culumbia University Press, New York, pp 69-88

Kuczynska-Kippen N, Joniak T (2009) Chlorophyll a and physicalchemical features of small waterbodies as indicators of land use in the Wielkopolska region (western Poland). Limnetica 29:163-170

Le Viol I, Mocq J, Julliard R, Kerbiriou C (2009) The contribution of motorway stormwater retention ponds to the biodiversity of aquatic macroinvertebrates. Biol Conserv 142:3163-3171

Marris E (2005) The forgotten ecosystem. Nature 437:944-945

Matson PA, Parton WJ, Power AG, Swift MJ (1997) Agricultural intensification and ecosystem properties. Nature 277:504-509

Mittelbach GG, Steiner CF, Scheiner SM, Gross KL, Reynolds HL, Waide RB, Willig MR, Dodson SI, Gough L (2001) What is the observed relationship between species richness and productivity? Ecology 82:2381-2396

Mittermeier RA, Gil PR, Hoffman M, Pilgrim J, Brooks T, Mittermeier CG, Lamoreux J, da Fonseca GAB (2005) Hotspots revisited: earth's biologically richest and most endangered terrestrial ecoregions. Conservation International, Arlington

Moore TLC, Hunt WF (2012) Ecosystem service provision by stormwater wetlands and ponds-a means for evaluation? Water Res 46:6811-6823

Motta PEF, Curi N, Franzmeier DP (2002) Relation of soils and geomorphic surfaces in the Brazilian Cerrado. In: Oliveira PS, Marquis RJ (eds) The Cerrados of Brazil. Culumbia University Press, New York

Müller C (2003) Expansion and modernization of agriculture in the Cerrado-the case of soybeans in Brazil's center-West.
Department of economics working paper 306. University of Brasilia, Brasilia

Myers N, Mittermeier RA, Mittermeier CG, da Fonseca GAB, Kent J (2000) Biodiversity hotspots for conservation priorities. Nature 403:853-858

OCDE (1982) Eutrophisation des eaux. Méthodes de surveillance, d'évaluation et de lutte. OCDE, Paris

Odum E, Barret GW (2005) Fundamentals of ecology. Thomson, Brooks/Cole, Belmont

Oertli B, Auderset Joye D, Castella E, Juge R, Lachavanne J-B (2000) Biological diversity and ecological typology of ponds and small lakes in Switzerland (in French). Project Report. OFEFP, Bern

Oertli B, Biggs J, Céréghino R, Grillas P, Joly P, Lachavanne JB (2005) Conservation and monitoring of pond biodiversity: introduction. Aquat Conserv Marine Freshw Ecosys 15:535-540

Oertli B, Biggs J, Cereghino R, Declerck S, Hull A, Miracle MR (2010) Pond conservation in Europe. Springer, Dordrecht

Oliveira Filho AT, Ratter JA (2002) Vegetation physiognomies and woody flora of the Cerrado biome. In: Oliveira PS, Marquis RJ (eds) The Cerrados of Brazil. Culumbia University Press, New York, pp 91-120

Oliveira PS, Marquis RJ (2002) The Cerrados of Brazil. Culumbia University Press, New York

Robin J, Wezel A, Bornette G, Arthaud F, Angélibert S, Rosset V, Oertli B (2014) Biodiversity in eutrophicated shallow lakes: determination of tipping points and tools for monitoring. Hydrobiologia 723:63-75

Rodgher S, EL Espíndola G, Rocha O, Fracácio R, Pereira RHG, Rodrigues MHS (2005) Limnological and ecotoxicological studies in the cascade of reservoirs in the Thietê river (São Paulo, Brazil). Braz J Biol 65:697-710

Rosset V, Angélibert S, Arthaud F, Bornette G, Robin J, Wezel A, Vallod D, Oertli B (2014) Is eutrophication really a major impairment for small waterbody biodiversity? J Appl Ecol 51:415-425

Sano EE, Barcelos AO, Bezerra HS (1999) Assessing the spatial distribution of cultivated pastures in the Brazilian savanna. Pasturas Trop 22:2-15

Scher O, Thiery A (2005) Odonata, amphibia and environmental characteristics in motorway stormwater retention ponds (Southern France). Hydrobiologia 551:237-251

Schiesari L, Grillitsch B (2011) Pesticides meet megadiversity in the expansion of biofuel crops. Front Ecol Environ 9:215-221

Symonds MRE, Moussalli A (2011) A brief guide to model selection, multimodel inference and model averaging in behavioural ecology using Akaike's information criterion. Behav Ecol Sociobiol 65:13-21

Tundisi JG, Matsumura-Tundisi T, Calijuri MC (1993) Limnology and managment of reservoirs in Brazil. In: Straskraba M, Tundisi JG, Duncan A (eds) Comparative reservoir limnology and water quality management. Springer, Netherlands, pp 25-55

Verdegem MCJ (2007) Nutrient balance in ponds. In: van der Zijpp AJ, Verreth JAJ, Le Quang T, van Mensvoort MEF, Bosma RH, Beveridge MCM (eds) Fishponds in farming systems. Wageningen Academic Publisher, Wageningen

Waide RB, Willig MR, Steiner CF, Mittelbach G, Gough L, Dodson SI, Juday GP, Parmenter R (1999) The relationship between productivity and species richness. Annu Rev Ecol Syst 30:257-300

Wezel A, Oertli B, Rosset V, Arthaud F, Leroy B, Smith R, Angélibert S, Bornette G, Vallod D, Robin J (2014) Biodiversity patterns of nutrient-rich fish ponds and implications for conservation. Limnology 15:213-223

Williams P, Whitfield M, Biggs J, Bray S, Fox G, Nicolet P, Sear D (2003) Comparative biodiversity of rivers, streams, ditches and ponds in an agricultural landscape in Southern England. Biol Conserv 115:329-341 